\title{
Hubungan Respon Time Keluarga dalam Membawa Pasien Stroke ke Pelayanan Kesehatan dengan Tingkat Keparahan Pasien Stroke
}

\author{
Linda Ishariani ${ }^{1}$, Diana Rachmania ${ }^{2}$ \\ ${ }^{1,2}$ Program Studi Sarjana Keperawatan, STIKES Karya Husada Kediri \\ *Alamat Korespondensi: Jl. Soekarno Hatta No.7, Darungan, Kec. Pare, Kediri, Jawa \\ Timur 64225 \\ Email: widiana1925@gmail.com
}

Diterima: 9 Juni 2021 | Disetujui: 16 Juni 2021

\begin{abstract}
Abstrak
Latar Belakang dan Tujuan: Stroke merupakan penyakit defisit neurologis akut yang disebabkan oleh gangguan pembuluh darah otak yang terjadi secara mendadak menimbulkan kecacatan atau kematian. Respon keluarga dalam membawa pasien stroke ke pelayanan kesehatan sangat penting sehingga tingkat keparahan stroke menjadi ringan. Tujuan penelitian ini adalah untuk mengetahui hubungan respon time keluarga dalam membawa pasien stroke ke pelayanan kesehatan dengan tingkat keparahan pasien stroke.

Desain Penelitian: Penelitian ini menggunakan korelasional dengan pendekatan cross sectional. Pengambilan sampel menggunakan teknik accidental sampling sebanyak 30 responden.

Hasil: Hampir setengah dari responden $(43,3 \%)$ berusia $36-45$ tahun, sebagian besar perempuan sejumlah 20 responden $(66,7 \%)$ dan sebagian besar mengalami serangan stroke 1 kali sejumlah 26 responden $(86,7 \%)$. Hasil menunjukkan hampir setengah dari responden memiliki respon time dalam membawa pasien stroke ke pelayanan kesehatan dengan kategori cepat sejumlah 11 responden $(36,7 \%)$ dan sebagian besar responden memiliki tingkat keparahan ringan sejumlah 16 responden $(53,3 \%)$. Analisis data didapatkan nilai $P$ value $0,0005<\alpha$ 0,05 berarti ada hubungan respon time keluarga dalam membawa pasien stroke ke pelayanan kesehatan dengan tingkat keparahan pasien stroke, dengan nilai coefficient corelation sebesar 0,834 artinya mempunyai hubungan yang sangat kuat dengan arah hubungan positif.
\end{abstract}

Simpulan dan Implikasi: Semakin cepat respon time keluarga dalam membawa pasien stroke ke pelayanan kesehatan, maka tingkat keparahan stroke semakin ringan. Diharapkan keluarga juga mampu mendeteksi dini gejala awal yang muncul pada pasien sehingga tingkat keparahan penyakit juga berkurang.

Kata kunci : Keluarga; Keparahan Stroke; Respon time

Sitasi: Ishariani, L \& Rachmania, D. (2021). Hubungan respon time keluarga dalam membawa pasien stroke ke pelayanan kesehatan dengan tingkat keparahan pasien stroke. The Indonesian Journal of Health Science. 13(1), 35-43. DOI: 10.32528/ijhs.v13i1.5274

Copyright: (C) 2021 Ishariani, et al. This is an open-access article distributed under the terms of the Creative Commons Attribution-NonCommercial 4.0 International License, which permits unrestricted use, distribution, and reproduction in any medium, provided the original author and source are credited.

Diterbitkan Oleh: Universitas Muhammadiyah Jember

ISSN (Print): 2087-5053

ISSN (Online): 2476-9614 


\begin{abstract}
Background and Aim: Stroke is an acute neurological deficiency disease caused by a brain blood vessel disorder that occurs suddenly causing disability or death. The family response in bringing stroke patients to health services is very important so that the severity of the stroke is light. The purpose of this study was to determine the relationship between family time response in bringing stroke patients to health services with the severity of stroke patients.

Methods: This design of this research was correlational with cross sectional approach. The sample was using accidental sampling technique of 30 respondents.

Results: The results showed that almost half of the 13 respondents (43.3\%) were aged 36-45 years, most of the women were 20 respondents (66.7\%) and most of them experienced a stroke once a number of 26 respondents (86.7\%). The results showed that almost half of the respondents had a response time in bringing stroke patients to health services with a fast category of 11 respondents $(36.7 \%)$ and most of the respondents had a mild severity of 16 respondents (53.3\%). The data analysis obtained a $P$ value of $0.000<\alpha 0.05$, which means that there was a relationship between family response time in bringing stroke patients to health services with the severity of stroke patients, with a correlation coefficient value of 0.834 which means that it had a very strong relationship with the direction of the positive relationship, which is the faster.

Conclusion: The response time of the family in bringing stroke patients to health services was good, the stroke severity was getting lighter. It was hoped that the family will also be able to detect early symptoms that appear in patients so that the severity of the disease is also reduced
\end{abstract}

Keywords: Family; Response Time; Severity of Stroke

\section{PENDAHULUAN}

Penyakit stroke bisa timbul mendadak disebabkan karena terjadinya gangguan peredaran darah otak dan bisa terjadi pada siapa saja dan kapan saja (Auliyah et al., 2018). Keberhasilan penanganan stroke dapat dipengaruhi oleh kecepatan, ketepatan dan kecermatan pada penanganan awal pasien stroke (Sari et al., 2019). Kecepatan keluarga dalam membawa pasin stroke ke layanan kesehatan dalam hal ini memiliki peran penting dalam keberhasilan pengobatan pasien stroke (Asmaria \& Yuderna, 2020).

Periode emas (golden period) dalam penanganan stroke adalah \pm 3 jam sejak awal terjadi serangan. Pasien harus segera mendapatkan terapi secara komprehensif dan optimal dari tim gawat darurat rumah sakit untuk mendapatkan hasil pengobatan yang optimal (Setianingsih et al., 2019). Penanganan yang optimal pada jam awal terjadinya stroke akan menurunkan angka kecacatan sebesar 30\% (Prasetyo, 2018).

Fenomena atau masalah yang terjadi saat ini yaitu masih banyaknya keluarga yang belum mampu atau tidak tahu tentang deteksi dini serangan stroke. Minimalnya tanda dan gejala yang muncul sebagai serangan stroke masih merupakan masalah utama keterlambatan manajemen setelah serangan stroke. Umumnya keluarga baru akan mencari pertolongan apabila terdapat gejala klinis dan gangguan 
fungsi yang berat, sedangkan gejala yang ringan kurang mendapatkan respon padahal gejala yang ringan ini juga dapat mengakibatkan kecacatan dan kematian bila tidak diatasi segera (Prasetyo, 2018). Stroke yang terlambat terdeteksi sangat berbahaya bahkan bisa menyebabkan pasien jatuh dalam keadaan yang lebih serius.

Menurut American Stroke Association (2016) hampir 800.000 (sekitar 795.00) orang di Amerika Serikat mengalami stroke yang baru atau berulang setiap tahun. Stroke merupakan penyebab utama yang menyebabkan kematian hampir 130.000 orang per tahun. Angka kejadian stroke sekitar 15 juta orang setiap tahunnya, diantaranya ditemukan jumlah kematian sebanyak 5 juta dan 5 juta orang lain mengalami kecacatan yang permanen serta sisanya kecacatan yang tidak permanen (WHO, 2013). Prevalensi penyakit stroke di Indonesia berdasarkan hasil riset kesehatan dasar (RISKESDAS) pada tahun 2018 adalah 12,4 per mil penduduk. Angka ini naik dibandingkan hasil RISKESDAS tahun 2018 yang sebesar $8,3 \%$.

Hasil studi pendahuluan di IGD RS Amalia Pare Kediri, didapatkan data jumlah pasien stroke yang masuk dalam 3 bulan terakhir sebanyak 95 pasien dari bulan Juli sampai September. Dari 6 keluarga pasien dengan stroke terdapat 4 keluarga sudah mengetahui tentang penyakit stroke, tetapi yang mereka ketahui penyakit stroke merupakan adanya kelumpuhan di salah satu bagian tubuh tetapi mereka tidak mengetahui golden period stroke sehingga pasien dibawa ke rumah sakit sudah melewati golden period.

Penyakit stroke merupakan salah satu penyakit tidak menular yang menjadi kekhawatiran banyak orang.
Stroke tergolong dalam cerebrovasculer disease (CVD) merupakan suatu penyakit defisist neurologis akut yang disebabkan oleh gangguan pembuluh darah otak yang terjadi secara mendadak dan dapat menimbulkan cacat atau kematian, serta menjadi gawat darurat dan membutuhkan pertolongan secepat mungkin (Wardani \& Santi, 2014).

Para ahli menganggap bahwa penyebab utama stroke pada umumnya adalah pasien stroke yang terbiasa mengkonsumsi makanan yang mengandung lemak jenuh yang menimbulkan aterosklerosis, yaitu menyempitnya pembuluh arteri disebabkan lemak yang menempel pada dinding arteri. Dalam hal ini ketika terjadi serangan stroke sangat membutuhkan penanganan yang cepat dan hal ini sangat dipengaruhi oleh respon keluarga dalam membawa pasien stroke ke pelayanan kesehatan.

Kewaspadaan terhadap stroke dengan pengenalan cepat terhadap tanda-tanda stroke harus segera dilakukan karena keberhasilan terapi stroke sangat ditentukan oleh kecepatan tindakan pada fase akut. Namun pada saat ini masih banyak keluarga yang belum mampu mendeteksi dini serangan stroke sehingga terlambat membawa pasien ke layanan kesehatan dan mengakibatkan banyaknya pasien stroke yang jatuh dalam kondisi parah serta berisiko mengalami kecacatan sampai kematian yang ditimbulkan dari serangan penyakit stroke yang terlambat terdeteksi (Arianto, 2016). Dampak buruk akibat penyakit stroke bisa dicegah salah satunya dari peran dan dukungan keluarga serta penanganan yang tepat tim petugas Kesehatan (Junaidi, 2011).

Keluarga yang merupakan bagian dari masyarakat sesungguhnya 
mempunyai peranan yang sangat penting. Keluarga mempunyai posisi yang strategis untuk dijadikan sebagai unit pelayanan kesehatan karena masalah kesehatan dalam keluarga saling berkaitan dan saling mempengaruhi antar anggota keluarga. Penyakit stroke merupakan kegawatdaruratan medis yang harus ditangani secara cepat, tepat dan juga cermat (Wardana, 2011). Dalam hal ini kemampuan dan peran keluarga yang komprehensif untuk mendeteksi serangan stroke dan selanjutnya segera membawa pasien ke pelayanan kesehatan sangat dibutuhkan untuk mendapatkan penanganan awal supaya tidak terjadi cacat permanen dan tidak terjadi keparahan stroke yang berat, yang mengakibatkan komplikasi dari penyakit stroke (Wirawan et al., 2013).

Berdasarkan hal tersebut membuat peneliti tertarik untuk meneliti permasalahan tentang hubungan respon time keluarga dalam membawa pasien stroke ke pelayanan kesehatan dengan tingkat keparahan pasien stroke. Peneliti ingin mengetahui salah satu faktor yang menyebabkan tingkat keparahan stroke yaitu respon time keluarga dari beberapa faktor yang mempengaruhi. Tujuan dari penelitian ini adalah untuk menganalisis respon time keluarga dalam membawa pasien stroke ke pelayanan kesehatan dengan tingkat keparahan pasien stroke.

\section{METODE PENELITIAN}

Desain penelitian yang digunakan adalah korelasional dengan pendekatan cross sectional. Variabel independen pada penelitian ini adalah respon time keluarga dalam membawa pasien stroke ke pelayanan kesehatan. Variabel dependennya yaitu tingkat keparahan penyakit stroke. Populasi dalam penelitian ini yaitu semua keluarga pasien dan pasien stroke yang dirawat di RS Amelia Pare Kediri selama 3 bulan terakhir (bulan JuliSeptember 2019) yang berjumlah 95 orang dan jumlah sampel sebanyak 30 responden dengan menggunakan teknik accidental sampling yang diambil pada bulan Maret 2020.

Instrumen yang digunakan untuk mengukur variabel independen menggunakan kuesioner untuk mengukur lama waktu keluarga dalam membawa anggota keluarga dengan stroke ke pelayanan kesehatan dan untuk variabel dependen menggunakan lembar observasi untuk mengevaluasi tingkat keparahan stroke, digunakan instrumen standar pengukuran menurut The National Institutes of Health Stroke Scale (NIHSS) dengan parameter penilaian meliputi penilaian terhadap fungsi bahasa, kesadaran, neglect, lapang pandang, pergerakan mata, kelumpuhan wajah, kekuatan motorik, fungsi sensorik dan koordinasi (Didik \& Rajin, 2017). Kriteria untuk variable independent adalah sebagai berikut: Cepat (1-3 jam), cukup lambat (4-6 jam), lambat (7-9 jam) dan sangat lambat (lebih dari 10 jam). Format skala NIHSS untuk variable dependen dengan penilaian keparahan ringan (1-4), keparahan sedang (5-15), keparahan berat (16-20) dan keparahan sangat berat (21-42).

Kuesioner untuk mengukur variable independen dan dependen telah diuji validitasnya dengan menggunakan Product Moment Pearson Correlation. Dasar pengambilan keputusan dari uji ini adalah jika nilai $r$ hitung pada masingmasing item pertanyaan lebih besar dari $r$ tabel maka instrumen tersebut dinyatakan valid (Sugiyono, 2013). R tabel dalam penelitian ini yaitu 0,754 dengan tingkat signifikasi $5 \%$ dan berdasarkan jumlah responden yang 
dipakai untuk uji coba instrumen sebanyak 7 responden.

Kuesioner untuk mengukur variable independent dan dependen telah diuji reliabitiasnya berdasarkan konsistensi internal dari skala dengan teknik cronbach alpha menggunakan program SPSS. Dasar pengambilan keputusan dari uji ini adalah jika nilai $r$ hitung (nilai cronbach alpha) lebih besar dari $r$ tabel maka instrumen tersebut dinyatakan reliabel (Sugiyono, 2013). R tabel dalam penelitian ini yaitu 0,754 dengan tingkat signifikasi $5 \%$ dan berdasarkan jumlah responden yang dipakai untuk uji coba instrumen sebanyak 7 responden.

Data hasil penelitian disajikan dalam bentuk distribusi frekuensi yang meliputi data umum (usia, jenis kelamin, pendidikan, pekerjaan, hubungan dengan pasien, serangan stroke dan informasi tentang deteksi dini stroke), serta data khusus (kemampuan keluarga dalam deteksi dini serangan stroke dan tingkat keparahan stroke). Data yang terkumpul selanjutnya diuji menggunakan uji statistik Spearman Rank dengan tingkat kemaknaan $(\alpha)$ $0,05 . \mathrm{H}_{1}$ diterima jika $p$-value $\leq \alpha 0,05$ (Nursalam, 2014).

\section{HASIL PENELITIAN}

Hasil pada tabel 1 diketahui hampir setengah responden yaitu 11 responden $(43,3 \%)$ berusia 36-45 tahun, sebagian besar atau 20 responden $(66,7 \%)$ berjenis kelamin perempuan, hampir setengah $(46,7 \%)$ berpendidikan SMA, sebagian besar $(53,3 \%)$ tidak bekerja, 22 responden $(73,3 \%)$ merupakan anak pasien, 26 responden $(86,7 \%)$ pernah 1 kali serangan stroke dan sebagian besar $(86,7 \%)$ sudah pernah mendapatkan informasi tentang deteksi dini serangan stroke. Distribusi frekuensi data khusus hasil penelitian dapat dilihat pada tabel 2 dan 3. Hasil tabulasi silang dapat dilihat pada tabel 4 .

Tabel 2 menunjukkan hampir setengah dari responden 11 responden $(36,7 \%)$ dengan kriteria respon time keluarga dalam membawa pasien stroke ke pelayanan kesehatan dengan kategori cepat. Sebagian besar responden 16 responden (53,3\%) mengalami tingkat keparahan stroke dengan kategori ringan (Tabel 3). Hasil uji statistik didapatkan ada hubungan antara respon time keluarga dengan tingkat keparahan pasien stroke. Semakin cepat respon time keluarga maka semakin ringan tingkat keparahan strokenya.

Tabel 1. Distribusi frekuensi karakteristik responden

\begin{tabular}{lcc}
\hline Karakteristik & \multicolumn{2}{c}{ Nilai } \\
\cline { 2 - 3 } & Jumlah & Persentase \\
\hline Umur Keluarga & 11 & $36,7 \%$ \\
25-35 tahun & 13 & $43,3 \%$ \\
$36-45$ tahun & 5 & $16,7 \%$ \\
$46-55$ tahun & 1 & $3,3 \%$ \\
56-65 tahun & & \\
\hline Jenis Kelamin Keluarga & 10 & $33,3 \%$ \\
Laki-laki & 20 & $66,7 \%$ \\
Perempuan & & \\
Pendidikan & 4 & $13,3 \%$ \\
SD/sederajat & 9 & $30,0 \%$ \\
SMP/sederajat & 14 & $46,7 \%$ \\
SMA/sederajat & 3 & $10,0 \%$ \\
Perguruan Tinggi & & \\
\hline
\end{tabular}




\begin{tabular}{|c|c|c|}
\hline \multirow[t]{2}{*}{ Karakteristik } & \multicolumn{2}{|c|}{ Nilai } \\
\hline & Jumlah & Persentase \\
\hline \multicolumn{3}{|l|}{ Pekerjaan } \\
\hline Tidak bekerja/IRT & 16 & $53,3 \%$ \\
\hline Petani/buruh tani & 5 & $16,7 \%$ \\
\hline PNS & 1 & $3,3 \%$ \\
\hline Swasta/lain-lain & 8 & $26,7 \%$ \\
\hline \multicolumn{3}{|l|}{ Hubungan dengan pasien } \\
\hline Suami & 2 & $6,7 \%$ \\
\hline Istri & 6 & $20,0 \%$ \\
\hline Anak & 22 & $73,3 \%$ \\
\hline \multicolumn{3}{|l|}{ Serangan stroke } \\
\hline Satu kali & 26 & $86,7 \%$ \\
\hline Dua kali & 4 & $13,3 \%$ \\
\hline \multicolumn{3}{|l|}{ Informasi deteksi dini stroke } \\
\hline Sudah & 26 & $86,7 \%$ \\
\hline Belum & 4 & $13,3 \%$ \\
\hline \multicolumn{3}{|c|}{ Sumber informasi deteksi dini serangan stroke } \\
\hline Petugas kesehatan & 5 & $16,7 \%$ \\
\hline Media elektronik & 12 & $40,0 \%$ \\
\hline Sumber lain & 9 & $30,0 \%$ \\
\hline Tidak ada sumber informasi & 4 & $13,3 \%$ \\
\hline \multicolumn{3}{|c|}{ Respon keluarga ketika terjadi serangan stroke } \\
\hline Segera ke IGD & 12 & $40,0 \%$ \\
\hline Membawa ke dokter praktek & 3 & $10,0 \%$ \\
\hline Membawa ke puskesmas & 9 & $30,0 \%$ \\
\hline Menghubungi keluarga/ tetangga terdekat & 4 & $13,3 \%$ \\
\hline Membawa ke pengobatan tradisional & 2 & $6,7 \%$ \\
\hline \multicolumn{3}{|l|}{ Umur pasien } \\
\hline 36-45 tahun & 1 & $3,3 \%$ \\
\hline $46-55$ tahun & 7 & $23,3 \%$ \\
\hline $56-65$ tahun & 11 & $36,7 \%$ \\
\hline$>65$ tahun & 11 & $36,7 \%$ \\
\hline \multicolumn{3}{|l|}{ Jenis kelamin } \\
\hline Laki-laki & 14 & $46,7 \%$ \\
\hline Perempuan & 16 & $53,3 \%$ \\
\hline \multicolumn{3}{|l|}{ Pendidikan } \\
\hline $\mathrm{SD} /$ sederajat & 17 & $56,7 \%$ \\
\hline SMP/sederajat & 8 & $26,7 \%$ \\
\hline SMA/sederajat & 4 & $13,3 \%$ \\
\hline Perguruan Tinggi & 1 & $3,3 \%$ \\
\hline \multicolumn{3}{|l|}{ Pekerjaan } \\
\hline Tidak bekerja/IRT & 15 & $50,0 \%$ \\
\hline Petani/buruh tani & 12 & $40,0 \%$ \\
\hline Swasta/lain-lain & 3 & $10,0 \%$ \\
\hline \multicolumn{3}{|l|}{ Riwayat penyakit keluarga dengan stroke } \\
\hline Ada & 1 & $3,3 \%$ \\
\hline Tidak ada & 29 & $96,7 \%$ \\
\hline \multicolumn{3}{|l|}{ Riwayat penyakit dahulu } \\
\hline Tekanan darah tinggi & 15 & $50,0 \%$ \\
\hline Diabetes mellitus & 4 & $13,3 \%$ \\
\hline Lain-lain & 11 & $36,7 \%$ \\
\hline
\end{tabular}


Tabel 3. Distribusi frekuensi tingkat keparahan pasien stroke

\begin{tabular}{clcc}
\hline \multicolumn{4}{c}{ Kriteria tingkat keparahan pada pasien stroke } \\
\hline No & Kriteria & Frekuensi & Persentase \\
\hline 1 & Keparahan Ringan & 16 & $53,3 \%$ \\
2 & Keparahan Sedang & 10 & $33,3 \%$ \\
3 & Keparahan Berat & 2 & $6,7 \%$ \\
4 & Keparahan Sangat Berat & 2 & $6,7 \%$ \\
\hline Total & & 30 & $100 \%$ \\
\hline
\end{tabular}

Tabel 4. Hubungan respon time keluarga dalam membawa pasien stroke ke pelayanan kesehatan dengan tingkat keparahan pasien stroke

\begin{tabular}{|c|c|c|c|c|c|c|c|c|c|c|c|}
\hline \multirow{3}{*}{$\begin{array}{c}\text { Repon } \\
\text { Time } \\
\text { Keluarga }\end{array}$} & \multicolumn{10}{|c|}{ Tingkat Keparahan } & \multirow{3}{*}{$\begin{array}{c}\mathrm{P} \\
\text { value } \\
0,00\end{array}$} \\
\hline & \multicolumn{2}{|c|}{ Ringan } & \multicolumn{2}{|c|}{ Sedang } & \multicolumn{2}{|c|}{ Berat } & \multicolumn{2}{|c|}{ Sangat Berat } & \multicolumn{2}{|c|}{ Total } & \\
\hline & $F$ & $\%$ & $\mathrm{~F}$ & $\%$ & $F$ & $\%$ & $\mathrm{~F}$ & $\%$ & $\mathrm{~F}$ & $\%$ & \\
\hline Cepat & 11 & 36,7 & 0 & 0 & 0 & 0 & 0 & 0 & 11 & 36,7 & $(<\alpha$ \\
\hline Cukup & 4 & 13,3 & 4 & 13,3 & 1 & 3,3 & 0 & 0 & 9 & 30 & $0,05)$ \\
\hline Lambat & & & & & & & & & & & \\
\hline Lambat & 0 & 0 & 6 & 20 & 0 & 0 & 0 & 0 & 6 & 20 & $\mathrm{R}=$ \\
\hline $\begin{array}{l}\text { Sangat } \\
\text { Lambat }\end{array}$ & 1 & 3.3 & 0 & 0 & 1 & 3,3 & 2 & 6,7 & 4 & 13,3 & 0,834 \\
\hline Total & 16 & 53,3 & 10 & 33,3 & 2 & 6,7 & 2 & 6,7 & 30 & 100 & \\
\hline
\end{tabular}

\section{PEMBAHASAN}

Pada penelitian ini didapatkan bahwa respon keluarga membawa anggota keluarga yang sakit ketika datang ke rumah sakit dalam waktu 1-3 jam setelah terjadi serangan sebanyak $11(36,7 \%)$ responden dengan kategori cepat. Hal ini penting karena penanganan stroke sedini mungkin akan mengurangi kematian dan meminimalkan kerusakan otak. Golden hour adalah istilah yang digunakan untuk menunjukkan waktu efektif penanganan stroke (Lingga, 2013). Penanganan dini yang paling direkomendasikan untuk stroke diberikan dalam rentang waktu kurang dari tiga jam (golden hour) setelah terjadinya serangan stroke. Hal ini sejalan dengan teori Hariyanti et.al (2015) yang menyatakan keberhasilan penanganan stroke sangat dipengaruhi oleh kemampuan keluarga dalam mendeteksi serangan stroke. Sealin itu juga pengetahuan akan faktor risiko terjadinya stroke juga merupakan hal yang penting karena dengan pemahaman seseorang terhadap faktor risiko suatu penyakit, maka upaya pencegahan secara tidak langsung akan dilakukan (Wardhani \& Martini, 2014).

Terlambatnya penanganan stroke di rumah sakit sekitar 83,9\% karena adanya keterlambatan pada fase pre-hospital. Penyebab dari keterlambatan penanganan pre-hospital stroke diantaranya adalah sikap menyepelekan dan kurangnya pengetahuan tentang tanda-tanda dini stroke (Santosa \& Trisnain, 2019). Waktu emas (golden hour) menjadi hal penting dalam penanganan stroke adalah \pm 3 jam, artinya dalam 3 jam awal setelah mendapatkan serangan stroke, karena penanganan stroke sedini mungkin akan mengurangi kematian dan meminimalkan kerusakan otak (Saudin, Agoes,\& Rini, 2016).

Berdasarkan hasil penelitian Zayyan (2019) hasil tersebut didapatkan distribusi klasifikasi tingkat 
keparahan stroke menggunakan NIHSS terbanyak adalah defisit neurologis ringan yang memiliki kisaran nilai NIHSS $<5$. Hasil ini sesuai dengan penelitian yang telah dilakukan di Iowa, Amerika Serikat bahwa dari 194 subjek yang diteliti sebanyak 86\% memiliki rentang nilai NIHSS 3-6 yang merupakan defisit neurologis ringan.

Pada penelitian didapatkan bahwa sebagian besar responden memiliki tingkat keparahan stroke ringan dengan skor 1-4, hal ini dikarenakan pemahaman keluarga tentang masalah kesehatan yang terjadi dapat menentukan tingkat keparahan penyakit serta bagaimana penanganan dan tindakan yang harus dilakukan oleh keluarga menurunkan risiko perburukan neurologis, meminimalkan kecacatan bahkan kematian.

Hal ini sejalan dengan observasi dengan menggunakan NIHSS sebagai prediktor independen terhadap keluaran pasien stroke, hal ini juga sesuai dengan hasil penelitian yang menyatakan bahwa terdapat hubungan yang signifikan antara NIHSS dan keluaran fungsional pasien stroke.

\section{SIMPULAN}

Respon time keluarga dalam membawa pasien stroke ke pelayanan kesehatan berhubungan dengan tingkat keparahan pasien stroke dengan tingkat keparahan pada pasien stroke. Artinya semakin cepat respon time keluarga membawa pasien stroke ke pelayanan kesehatan, maka semakin ringan tingkat keparahan stroke.

\section{SARAN}

Hasil penelitian ini diharapkan dapat dijadikan sebagai sumber pengetahuan yang baru bagi pihak keluarga dan diharapkan juga hasil penelitian ini dapat dijadikan acuan oleh keluarga tentang pentingnya respon keluarga dalam membawa pasien stroke ke pelayanan kesehatan sehingga penanganan yang cepat dan tepat akan meningkatkan keberhasilan dalam perawatan pasien stroke. Bagi petugas kesehatan diharapkan dapat memberikan edukasi pada masyarakat tentang deteksi dini dan penanganan segera pada pasien stroke.

\section{DAFTAR PUSTAKA}

Arianto, D. (2016). Uji metode act fast (face, arm, speech, time) terhadap tingkat pengetahuan keluarga lansia tentang tanda dan gejala stroke. Jurnal Keperawatan Muhamadiyah, 1(1)

Asmaria, M \& Yuderna, V. (2020). Study fenomenologi pengalaman keluarga pasien dalam penanganan prehospital pasca deteksi dini stroke. Jurnal Kesehatan Medika Saintika, 11(2).

doi: Http://Dx.Doi.Org/10.30633 /Jkms.V11i2.865

Auliyah, H., Hayati, F., \& Rachmania, D. (2018). Pengaruh mirror therapy of the face terhadap kemampuan otot wajah pada pasien stroke di RSUD Kabupaten Kediri. Jurnal Ilkes (Jurnal Ilmu Kesehatan), 9(1), 79.

Badan Penelitian dan Pengembangan Kesehatan Kementria RI. Riset kesehatan dasar (RISKESDAS) 2018. Laporan Nasional

Hariyanti, T., Harsono \& Prabandari, Y. (2015). Health seeking beavior on stroke patients. Jurnal Brawijaya, Vol.28, no.3

Junaidi, I. (2011). Stroke waspadai ancamannya. Yogyakarta : Andi 
Lingga, L. (2013). All about stroke. Jakarta: Gramedia

Nursalam. 2014. Konsep dan penerapan metodologi ilmu keperawatan. Jakarta: Salemba Merdeka

Prasetyo, E. (2018). Faktor-faktor yang mempengaruhi keterlambatan pasien stroke akut datang ke lima rumah sakit pemerintah di DKI Jakarta. Majalah Kesehatan Pharmamedika, Volume 9(1), 040.

https://doi.org/10.33476/mkp.v9i 1.674

Santosa, W \& Tisnain, A. (2019). Pengaruh dari pendidikan kesehatan tentang pre-hospital stroke terhadap pengetahuan dan self-efficacy masyarakat di Desa Jongbiru Kecamatan Gampengrejo Kabupaten Kediri dalam melakukan tindakan pertolongan prehospital stroke. Jurnal Gawat Darurat, 1(1)

Sari, L. M., Yuliano, A., \& Almudriki, A. (2019). Hubungan pengetahuan dan sikap keluarga terhadap kemampuan deteksi dini serangan stroke iskemik akut pada penanganan pre hopsital. Jurnal Kesehatan Perintis (Perintis's Health Journal), 6(1), 74-80.

https://doi.org/10.33653/jkp.v6i1 .241

Saudin, D \& Rajin, M. (2017). Metode pengkajian neurologis menggunakan national institutes of health stroke scale (NIHSS) pada pasien stroke di Instalasi Gawat Darurat RSUD dr. Iskak Tulungagung. Jurnal EDUNursing, 1(1).

Saudin, D. Agoes, A. Setyorini, I. (2016). Analisis faktor yang mempengaruhi keterlambatan dalam mengatasi pasien stroke saat merujuk ke RSUD Jombang. Jurnal Hesti Wira Sakti 4(2): 112.

Setianingsih, S., Darwati, L. E., \& Prasetya, H. A. (2019). Study deskriptif penanganan prehospital stroke life support pada keluarga. Jurnal Perawat Indonesia, $3(1), \quad 55$. https://doi.org/10.32584/jpi.v3i1. 225

Sugiyono. (2013). Metode penelitian kuantitaf, kualitatif dan $R \& D$. Bandung: Alfabeta

Wardhana, W. A. (2011). Strategi mengatasi \& bangkit dari stroke. Yogyakarta: Pustaka Pelajar.

Wardhani, N \& Martini, S. (2014). Faktor yang berhubungan dengan pengetahuan tentang stroke pada pekerja institusi pendidikan. Jurnal Berkala Epidemiologi, 2(1)

Wirawan, N., Bagus, I \& Putra, K. (2013). Prehospitalized management on acute stroke.: 115.

WHO. (2013). WHO publishes definitive atlas on global heart disease and stroke epidemic. http://www.who,int/mediacenter/ news/releases/2004/pr68/

index.html. Diakses tanggal 29 Juni 2020

Zayyan, M (2020) Hubungan antara tekanan darah dengan keparahan stroke menggunakan National Institute Health Stroke Scale. Jurnal Biomedika Kesehatan, 3(1):15-20. doi:10.18051/JBiomedKes.2020. v3.15-20 